\title{
Szkolnictwo wyznaniowe i nauczanie religii w świetle osobistych zapisków prymasa Stefana Wyszyńskiego z 1961 roku
}

\begin{abstract}
Religious education and teaching religion in Primate Stefan Wyszyński's personal notes from 1961

This article presents educational issues in the Polish People's Republic as presented in Primate Stefan Wyszyński's personal notes (called pro memoria) from 1961. The major source of the study is a Stefan Wyszyński manuscript stored in the Archdiocese Archive in Gniezno. In the first part of the study, an outline of research into education in the Polish People's Republic is presented, together with methodological issues. The second part is devoted to a brief summary of education against the ideological pressure exerted by the Communist authorities by 1961. The third part presents the characteristics of the source representing the basis of the study. The fourth part presents (in the light of Primate Wyszyński's notes) the act on the development of education and upbringing from 1961, care and education institutions of the Roman Catholic Church, kindergartens managed by nuns and parishes, religious education, church secondary education, religious instruction, lower seminaries, higher seminaries, tertiary education and academic religious leadership.
\end{abstract}

Keywords: education in the Polish People's Republic, religious education, primate Stefan Wyszyński, seminaries, religious instruction

Celem artykułu jest prezentacja problematyki oświatowej PRL w świetle osobistych zapisków prymasa Stefana Wyszyńskiego (zwanych pro memoria) z $1961 \mathrm{r}$. W pierwszej części opracowania przedstawiono zarys stanu badań nad oświatą w PRL oraz kwestie metodologiczne. Część druga poświęcona została krótkiej charakterystyce oświaty w Polsce „ludowej”, pod kątem ideologizacji do 1961 r. Część trzecia dotyczy charakterystyki źródła, stanowiącego podstawę opracowania. Część czwarta ukazuje - w świetle zapisków prymasa Wyszyńskiego - zagadnienia, takie jak: Ustawa o rozwoju systemu 
oświaty i wychowania z 1961 r. ${ }^{1}$, instytucje opiekuńczo-wychowawcze Kościoła rzymskokatolickiego, przedszkola zakonne i parafialne, szkolnictwo wyznaniowe, konfesyjne szkolnictwo średnie, katechizacja, niższe seminaria duchowne, wyższe seminaria duchowne, szkolnictwo wyższe oraz duszpasterstwo akademickie.

\section{Stan badań i zagadnienia metodologiczne}

Stan badań nad edukacją i polityką oświatową w PRL, w tym szkolnictwa wyznaniowego uznać należy za zaawansowany. Na rynku wydawniczym pojawiły się znaczące opracowania zarówno monograficzne, jak i cząstkowe dotyczące szkolnictwa poszczególnych szczebli, a także syntezy ogólne, ujmujące problematykę edukacyjną w skonkretyzowanej perspektywie badawczej, takiej jak: założenia programowe, struktura organizacyjna, polityka oświatowa $\mathrm{w}$ fazie jej tworzenia i realizacji, prawo oświatowe, sprawy kadrowe, programy oraz treści nauczania i in. ${ }^{2}$ Uwagę zwracają pozycje pisane w ujęciu komparatystycznym, których autorzy analizują edukację PRL, porównując ją z systemem oświaty wybranych krajów byłego bloku wschodniego, czy biorąc pod uwagę szerszy zakres, pod względem geograficznym i chronologicznym ${ }^{3}$.

Studia ogólne próbują uporządkować i uchwycić rzeczywistość szkolną PRL w określonym kluczu interpretacyjnym. W związku z dążeniem do uogólnienia zachodzących w przestrzeni edukacyjnej procesów, prezentowanie wydarzeń według przyjętego w opracowaniu klucza sprawia, że autorzy bardziej lub mniej wiernie odtwarzają opisywaną rzeczywistość, a może przybliżają się do niej. Uprawianie historiografii w formie szeroko zakrojonych syntez, choć obarczone ryzykiem nadmiernych uogólnień, wydaje się jednak niezbędne dla prób budowy, chociażby wstępnej, całościowej systematyki badanego zagadnienia. Dostępne pozycje syntetyczne uzupełnia i wzbogaca literatura wspomnieniowa, dzienniki, pamiętniki, relacje, które rejestrują wydarzenia z perspektywy świadka, czy uczestnika wydarzeń. Choć tego typu pozycje charakteryzuje duży stopień

${ }^{1}$ Ustawa z 15 lipca 1961 r. o rozwoju systemu oświaty i wychowania. Dz.U. 1961, nr 32, poz. 160.

2 Wybrane pozycje: J.W. Wołoszyn, Szkoła jako instrument politycznej legitymizacji władzy partii komunistycznej w Polsce (1944-1989), Lublin 2015; S. Mauersberg, M. Walczak, Szkolnictwo polskie po drugiej wojnie światowej (1944-1956), Warszawa 2005; S. Mauersberg, Nauczyciel wobec indoktrynacji komunistycznej w latach 1947-1956, „Przegląd Historyczno-Oświatowy” 2004, nr 3/4, s. 53-58; K. Kosiński, O nowa mentalność. Życie codzienne w szkołach 1945-1956, Warszawa 2000 i in.

3 J. Connelly, Zniewolony uniwersytet. Sowietyzacja szkolnictwa wyższego w Niemczech wschodnich, Czechach i Polsce 1945-1956, Warszawa 2013; J. Wojdon, Świat elementarzy. Obraz rzeczywistości w podręcznikach do nauki czytania w krajach bloku radzieckiego, Warszawa 2015; J. Draus, R. Terlecki, Historia wychowania, t. 2: Wiek XIX i XX, Kraków 2005.

${ }^{4} \mathrm{Na}$ tego typu problem uwrażliwiał m.in. Krzysztof Kosiński. W recenzji pozycji: J. Connelly, Zniewolony uniwersytet ..., zwrócił uwagę, że: „Z polskiego punktu widzenia komparatystyka skutkuje [...] nieuniknioną relatywizacją doświadczenia komunizmu”. Szerzej zob. K. Kosiński, Polski przypadek szczególny, „Pamięć i Sprawiedliwość" 2014, nr 2, s. 501. 
subiektywności, tak w warstwie opisu, jak i formułowanych ocen, należą do źródeł istotnych z punktu widzenia warsztatu historyka, pomocnych w odkrywaniu złożoności badanych zjawisk oraz poznania osób uczestniczących w wydarzeniach. Tego typu literatura posiada niebagatelne znaczenie dla lepszego zrozumienia ludzkich motywacji i wynikających z nich postaw ${ }^{5}$. Choć stanowi źródło stosunkowo często wykorzystywane przez autorów opracowań syntetycznych, publikacja udostępnianych stopniowo do druku dzienników, wspomnień, stanowi nadal wyzwanie dla badaczy. Do omawianej kategorii źródeł zaliczyć należy przygotowywane do druku i sukcesywnie wydawane pro memoria prymasa Stefana Wyszyńskiego. Z punktu widzenia badań nad historią szkolnictwa w PRL, szczególnie istotny wydaje się tom z 1961 r., a więc napisany w roku ogłoszenia pierwszej powojennej ustawy oświatowej, która uregulowała całokształt spraw dotyczących szkolnictwa PRL, a także zorganizowanych, instytucjonalnych oddziaływań wychowawczych o charakterze pozaszkolnym ${ }^{6}$.

\section{Zarys problematyki edukacyjnej w Polsce „ludowej” do 1961 roku}

Wprowadzona przez władze partyjno-rządowe ideologizacja szkolnictwa, połączona organicznie z programem indoktrynacji komunistycznej dzieci i młodzieży, dotyczyła wszystkich szczebli edukacyjnych: od przedszkola po uniwersytet i rozciągała się na oddziaływania poza systemem oświaty i wychowania. Dążeniem władz Polski „ludowej” było całkowite przejęcie kontroli nad kierunkiem wychowania najmłodszych obywateli, którzy w tym aspekcie potraktowani zostali poniekąd jako własność decydentów polityki oświatowej, występujących w roli ,ideologicznego rodzica" ". Pierwszą ofensywę ideologiczną w oświacie zapoczątkowaną po przejęciu władzy przez komunistów, wyhamował okres odwilży popaździernikowej. Liberalizacja kursu na polu oświatowym nie trwała zbyt długo. Choć nieodwracalnie doprowadzono do usunięcia z programów nauczania i wychowania zwulgaryzowanych treści ideologicznych, które w okresie stalinizmu zastępowały treści nauczania, założenia fundamentalne nie uległy zmianie, zwłaszcza te, dotyczące ideologicznych podstaw przejęcia przez władze partyjno-rządowe oświaty. Projekt ideologiczny władz PRL nadal znajdował swój wyraz w rozwiązaniach programowych, strukturalnych, organizacyjnych i kadrowych w edukacji. Po 1957 r. nastąpiła druga ofensywa ideologiczna w oświacie. Zaostrzenie kursu w polityce edukacyjnej sygnalizowały hasła odrzucenia „popaździernikowego liberalizmu”, przez który rozumiano rezygnację z dotychczas aprobowanego narzucania młodzieży światopoglądu materialistycznego. Władysław Gomułka upominał się o przywrócenie szkole „socjalistycznego”

${ }^{5}$ Szerzej zob. K. Karolczak (red.), Pamiętniki, dzienniki i relacje jako źródła do badań historycznych (XVIII-XX wiek), Kraków 2011, s. 5-6.

${ }^{6}$ Ustawa z 15 lipca 1961 r. o rozwoju systemu oświaty i wychowania. Dz.U. 1961, nr 32, poz. 160.

7 Szerzej zob. J.W. Wołoszyn, op. cit., s. 99. 
oblicza. IX Plenum KC PZPR z 1957 r. wymieniało najważniejsze zadania w dziedzinie polityki oświatowej, takie jak przejęcie opieki nad młodzieżą przez państwo oraz odbudowę jednolitego i dyspozycyjnego wobec partii komunistycznej ruchu młodzieżowego ${ }^{8}$. Zintensyfikowano przerwaną $\mathrm{w}$ okresie odwilży akcję laicyzacji szkół. Na podstawie okólnika ministra oświaty z 4 VIII 1958 r., przeprowadzono dekrucyfikację pomieszczeń szkolnych ${ }^{9}$. Wydane tego samego dnia, co okólnik, zarządzenie ministerialne pozbawiało osoby duchowne prawa nauczania i wychowania dzieci oraz młodzieży w ramach systemu oświaty ${ }^{10}$.

Podsumowując okres budowy tzw. socjalistycznej szkoły, Gomułka podczas plenum KC PZPR w styczniu 1961 r. stwierdził: Obecnie dojrzały warunki do powzięcia decyzji o reformie szkolnictwa. W swoim wystąpieniu nie pominął kwestii światopoglądowych: $W$ centrum uwagi instancji i organizacji partyjnych powinno znajdować się ideologiczne wychowanie młodzieży, kształtowanie jej postawy moralnej i politycznej ${ }^{11}$. Przyjęte założenia doczekały się ustawowego zadekretowania 15 lipca 1961 r., Ustawą o rozwoju systemu oświaty i wychowania, która obowiązywała przez niemal trzydzieści lat ${ }^{12}$.

\section{Charakterystyka źródła}

Podstawę źródłową opracowania stanowi rękopis sporządzony przez prymasa Stefana Wyszyńskiego, przechowywany w Archiwum Archidiecezjalnym w Gnieźnie ${ }^{13}$. Źródło jest aktualnie przedmiotem intensywnych badań i prac edytorskich, prowadzonych przez zespół naukowy, powołany w ramach projektu Narodowego Programu Rozwoju Humanistyki pt. „Opracowanie merytoryczne i redakcyjne niepublikowanych zapisków kard. Stefana Wyszyńskiego Pro memoria". Kierownikiem projektu został prof. zw. dr. hab. Jan Żaryn. Projekt finansowany jest przez Ministerstwo Nauki i Szkolnictwa Wyższego w ramach programu pod nazwą „Pomniki polskiej myśli filozoficznej, teologicznej i społecznej XX i XXI wieku". Wnioskodawcą projektu był Wydział Nauk Historycznych i Społecznych Uniwersytetu Kardynała Stefana Wyszyńskiego ${ }^{14}$. W efekcie prowadzo-

${ }^{8}$ Ibidem, s. 103-104.

${ }^{9}$ Okólnik Ministerstwa Oświaty nr 26 z 4 VIII 1958 r. w sprawie przestrzegania zasad świeckości szkoły. Dziennik Urzędowy Ministerstwa Oświaty 1958, nr 9, poz. 123.

10 Zarządzenie Ministra Oświaty z 4 VIII 1958 r. w sprawie nauczycieli religii. Dziennik Urzędowy Ministerstwa Oświaty 1958, nr 9, poz. 121.

11 W. Gomułka, Przemówienie końcowe nad pierwszym punktem porządku obrad VII Plenum KC PZPR wygłoszone 21 I 1961 r., w: Przemówienia 1961, idem, Książka i Wiedza, Warszawa 1962, s. 11.

12 Ustawa z 15 lipca 1961 r. o rozwoju systemu oświaty i wychowania. Dz.U. 1961, nr 32, poz. 160.

13 Archiwum Archidiecezji Gnieźnieńskiej (dalej: AAG), S. Wyszyński, Pro memoria, 1961 r.

14 Wykaz wniosków zakwalifikowanych do finansowania w konkursie programu pod nazwą „Pomniki polskiej myśli filozoficznej, teologicznej i społecznej XX i XXI wieku”, https://www.archiwum.nauka.gov.pl/ g2/oryginal/2016_10/8f83f6cb74a467445481934aa5d860ed.pdf [dostęp: 5.12.2018]. 
nych prac powstaje seria źródłowa pt. Pro memoria. Przewodniczącym redakcji naukowej Pro memoria został prof. dr hab. Paweł Skibiński, a wydawcami następujące podmioty: Archidiecezja Gnieźnieńska, Archidiecezja Warszawska, Instytut Pamięci Narodowej - Komisja Ścigania Zbrodni przeciwko Narodowi Polskiemu oraz Wydawnictwo Naukowe Uniwersytetu Kardynała Stefana Wyszyńskiego ${ }^{15}$. Seria realizowana jest pod redakcją dr. Rafała Łatki w ramach Centralnego Projektu Badawczego Instytutu Pamięci Narodowej pt. „Władze komunistyczne wobec Kościołów i związków wyznaniowych w Polsce 1944-1989". Ukazujące się sukcesywnie tomy, wchodzące w jej skład, stanowią jednocześnie odrębny, zamknięty cykl większej serii wydawniczej IPN: „Kościół katolicki w dokumentach". Na serię Pro memoria składają się tomy obejmujące poszczególne lata życia kard. Wyszyńskiego: od 1948 r., a więc od roku objęcia prymasostwa, do tomu zamykającego życie i kończącego sprawowanie urzędu przez wybitnego hierarchę. Do tej pory na rynku wydawniczym ukazały się cztery tomy Pro memoria, z następujących lat: tom 1: 1948-1952; tom 2: $1953 \mathrm{r}$.; tom 3: 1953-1956; tom 4: $1958 \mathrm{r}^{16}$

Rękopis prymasa z $1961 \mathrm{r}$. jest dobrze zachowany, a jego czytelność nie budzi większych zastrzeżeń. Na oryginalne zapiski z 1961 r. składa się 314 kart formatu A5. Prymas prowadził zapiski dość systematycznie, choć nie codziennie. Najczęściej rezygnował $\mathrm{z}$ notatek $\mathrm{w}$ okresie, kiedy podupadał na zdrowiu, lub korzystał z wypoczynku. Przy uwzględnieniu powyższych uwag, potwierdzić należy wyżej sformułowaną tezę, że źródło zachowało charakter dokumentu spisywanego na bieżąco i w miarę systematycznie. Źródło przygotowywane do druku cechuje wysoka wartość poznawcza. Z jednej strony zapiski to zarys indywidualnego portretu autora, czy wymienianych na kartach Pro memoria postaci, z drugiej - portret zbiorowy Kościoła i społeczeństwa PRL z początku lat 60., w szerokim przekroju społecznym i zawodowym. Prymas zatrzymuje się również nad środowiskiem polonijnym, ze szczególnym uwzględnieniem przedstawicieli emigracji nurtu niepodległościowego ${ }^{17}$.

Czytelnika zainteresowanego historią oświaty i szkolnictwa w PRL po 1956 r., zainteresują z pewnością wątki dotyczące relacji państwo-Kościół w tym obszarze, a więc kwestie szkolnictwa, szczególnie wyznaniowego, polityki wyznaniowej i oświatowej PRL.

${ }^{15}$ W skład rady programowej Pro memoria wchodzą: bp prof. dr hab. Jan Kopiec jako przewodniczący, Iwona Czarcińska, ks. prof. Bogdan Czyżowicz, prof. dr hab. Antoni Dudek, dr Tadeusz Krawczak, ks. prof. dr hab. Józef Marecki, ks. prof. dr hab. Krzysztof Pawlina, bp dr Marek Solarczyk, prof. dr hab. Jan Żaryn.

${ }^{16}$ S. Wyszyński, Pro memoria, t. 1: 1948-1952, red. i oprac. P. Skibiński, Warszawa - Gniezno, Archidiecezja Gnieźnieńska, Archidiecezja Warszawska, IPN, Wydawnictwo Naukowe UKSW, 2017; S. Wyszyński, Pro memoria, t. 2: 1953, red. i oprac. E. Czaczkowska, Warszawa - Gniezno, Archidiecezja Gnieźnieńska, Archidiecezja Warszawska, IPN, Wydawnictwo Naukowe UKSW, 2017; S. Wyszyński, Pro memoria, red. i oprac. I. Czarcińska, A. Gałka, 2018; S. Wyszyński, Pro memoria, t. 5: 1958, red. i oprac. M. Krupecka, Warszawa - Gniezno, Archidiecezja Gnieźnieńska, Archidiecezja Warszawska, IPN, Wydawnictwo Naukowe UKSW, Warszawa 2018.

${ }_{17}$ AAG, S. Wyszyński, Pro memoria, 1961 r. 


\section{Edukacja w świetle zapisków prymasa Wyszyńskiego z 1961 r.}

Podsumowując rok 1961 prymas stwierdził, że był to dla Kościoła czas pełen udręk ${ }^{18}$. Narastające napięcia w zakresie stosunków wyznaniowych PRL z początku lat 60 . XX w. ${ }^{19}$ wynikało ze skutków polityki władz partyjno-rządowych, które nie przewidywały miejsca dla rzeczywistej obecności Kościoła w sferze publiczno-prawnej. Postrzegały bowiem Kościół jako wroga, rywala ideologicznego oraz politycznego. Walka państwa z Kościołem o „rząd dusz” uwidoczniła się przede wszystkim na polu oświatowym. Doczekała się przy tym wyartykułowania prawnego, wieńczącego dotychczasowy proces laicyzacji wychowania ${ }^{20}$, wdrażany na wszystkich poziomach edukacyjnych. Przyjęte rozwiązania normatywne, wprowadzały monopol państwa w dziedzinie oświaty i wychowania $^{21}$, w których faktyczny udział sektora prywatnego oraz inicjatywy społecznej, a przede wszystkim podmiotowo traktowanego społeczeństwa, w tym rodziców, był nie do pogodzenia z przyjętym kierunkiem monopolizacji i upartyjnienia oświaty.

\section{Ustawa}

Ustawa z 15 lipca 1961 r. o rozwoju systemu oświaty i wychowania ${ }^{22}$, zadekretowała wprzęgnięcie szkolnictwa w projekt budowy tzw. państwa socjalistycznego ${ }^{23}$. Państwo zawłaszczyło sferę edukacyjną, rozciągając monopol nawet nad pozaszkolnymi instytucjonalnymi oddziaływaniami oświatowymi oraz wychowawczymi ${ }^{24}$. Choć de iure rezerwowano miejsce dla innych rozwiązań, łudząc społeczeństwo co do wolności zakładania

18 AAG, S. Wyszyński, Pro memoria, 31 XII 1961.

19 Szerzej zob. A. Dudek, R. Gryz, Komuniści i Kościól w Polsce (1945-1989), Wydawnictwo Znak, Kraków 2006, s. 160-216.

${ }^{20}$ „Szkoły i inne placówki oświatowo-wychowawcze są instytucjami świeckimi. Całokształt nauczania i wychowania w tych instytucjach ma charakter świecki” (artykuł 2). Dz.U. 1961, nr 32, poz. 160.

${ }^{21}$ „Wszelka pozaszkolna działalność oświatowa i wychowawcza oraz inne formy pracy z dziećmi i młodzieżą podlegają nadzorowi Ministra Oświaty, który może ustalać zasady i warunki prowadzenia tej działalności lub pracy" (artykuł 39 pkt 1). Dz.U. 1961, nr 32, poz. 160.

22 Ustawa z 15 lipca 1961 r. o rozwoju systemu oświaty i wychowania. Dz.U. 1961, nr 32, poz. 160.

${ }^{23}$ Założenia ideologiczne: „Oświata i wychowanie stanowią jedną z podstawowych dźwigni socjalistycznego rozwoju Polskiej Rzeczypospolitej Ludowej. System kształcenia i wychowania ma na celu przygotowanie kwalifikowanych pracowników gospodarki i kultury narodowej, świadomych budowniczych socjalizmu" (fragm. preambuły Ustawy). „Nauczanie i wychowanie w szkołach i innych placówkach oświatowo-wychowawczych ma na celu wszechstronny rozwój uczniów i wychowanie ich na świadomych i twórczych obywateli Polskiej Rzeczypospolitej Ludowej. [...] Szkoły i inne placówki oświatowo-wychowawcze wychowują w duchu socjalistycznej moralności i socjalistycznych zasad współżycia społecznego" (artykuł 1). Dz.U. 1961, nr 32, poz. 160 .

24 „Państwo zakłada, prowadzi i utrzymuje szkoły i inne placówki oświatowo-wychowawcze” (artykuł 4 pkt 1). Dz.U. 1961, nr 32, poz. 160. 
i prowadzenia placówek oświatowych przez podmioty pozapaństwowe, w praktyce ograniczono ich liczbę do podporządkowanego grona, nierzadko koncesjonariuszy partyjnych, usuwając $\mathrm{w}$ ten sposób ostatnie przeszkody na drodze wdrażania jednolitej linii wychowawczej, której kierunek dyktowały założenia filozofii marksistowskiej oraz wytyczne PZPR ${ }^{25}$.

Ustawa oświatowa stanowiła przedmiot obrad Komisji Wspólnej Rządu i Episkopatu ${ }^{26}$, której posiedzenie odbyło się 11 VII 1961 r. Ogłoszenie aktu prawnego przez państwo przypadło na okres wakacyjny. Prymas Wyszyński przebywał wówczas na urlopie w Stryszawie ${ }^{27}$. W swoich zapiskach z 17 lipca odnotował, że w miejscu wypoczynku wizytę złożył mu bp Zygmunt Choromański² ${ }^{28}$, przedstawiciel Episkopatu ds. stosunków państwa z Kościołem. Biskup Choromański zrelacjonował posiedzenie Komisji, oceniając, że strona państwowa z jednej strony próbowała poniekąd zastraszyć biskupów, by „milczeli”, tzn. nie zabierali oficjalnie głosu w sprawie wprowadzanej ustawy. Z drugiej strony, chciano zaskarbić sobie przychylność władz kościelnych, usprawiedliwiając się następująco: ustawy ustawami, a decydować będa zarządzenia wykonawcze. Wypowiedź złagodzić miała antykościelny i ideologiczny wydźwięk aktu oraz oznaczać, że roszczenia Kościoła, co do obecności w przestrzeni edukacyjnej będą przez państwo nadal rozpatrywane. Ustawy nie należało więc traktować jako przepisu prawnego, który zamknął definitywnie drogę szkolnictwu wyznaniowemu, czy nauczaniu religii. Prymas zastanawiał się nad podjęciem odpowiednich kroków, w celu oprotestowania rozwiązań ustawowych. Zapewne nie spodziewał się, że przyszłe zarządzenia wykonawcze poprawią sytuację Kościoła w obszarze oświaty. Obietnice traktował jako działania taktyczne, obliczone na „wyciszenie” niezadowolenia społecznego ${ }^{29}$. Dowodów, że państwo nie chce jakichkolwiek przejawów religijności w oświacie było wiele. Wdrażaniu koncepcji szkoły ateistycznej służyło usuwanie wszelkich elementów religijnych, laickie programy wychowania i nauczania, deklerykalizacja kadr oświatowych oraz likwidacja szkolnictwa konfesyjnego ${ }^{30}$.

25 „Rada Ministrów określa w drodze rozporządzenia zasady zakładania i utrzymywania szkół i innych placówek oświatowo-wychowawczych” (artykuł 4 pkt 2). „Szkoły, placówki oświatowe, wychowawcze, opiekuńczo-wychowawcze i inne zakłady lub placówki szkolne mogą być prowadzone przez organizacje zawodowe, młodzieżowe, instytucje społeczne oraz inne organizacje i instytucje, osoby prawne lub fizyczne, tylko za zezwoleniem Ministra Oświaty, na określonych przez niego zasadach i warunkach i pod jego nadzorem" (artykuł 39 pkt 1). Dz.U. 1961, nr 32, poz. 160.

${ }^{26}$ Komisja Wspólna Rządu i Episkopatu - powstała z inicjatywy prymasa Wyszyńskiego w 1949 r. Początkowo działa jako Komisja Mieszana. Celem Komisji było uzgadnianie spraw wyznaniowych.

27 W Stryszawie-Siwcówce znajdował się dom zakonny sióstr zmartwychwstanek. Prymas miał zwyczaj przyjeżdżać do domu sióstr na wypoczynek. Wśród odwiedzających tu prymasa był m.in. Karol Wojtyła.

${ }^{28}$ Zygmunt Choromański (1892-1968), biskup pomocniczy warszawski 1946-1968, sekretarz KEP 19461968, członek Komisji Mieszanej, następnie Komisji Wspólnej Rządu i Episkopatu.

29 AAG, S. Wyszyński, Pro memoria, 17 VII 1961.

30 S. Wyszyński, Wezwanie do sióstr wychowawczyń. Wawer 1961, w: idem, Dzieła zebrane, t. 7: 1961, Warszawa 2008, s. 303. 
Ustawa z 1961 r. sankcjonowała prawnie zasadę świeckości wychowania i nauczania, pojmowaną jako walkę z religią i jej nieobecność w przestrzeni szkolnej. Interpretacja tego zapisu, aspirującego do miana szkoły nowoczesnej i światopoglądowo neutralnej, w rzeczywistości opierała się na sowieckim modelu rozdziału religii od państwa, który nacechowany był wrogością wobec Kościoła i wiary ${ }^{31}$. Ustawa z 1961 r. zapobiegać miała przenikaniu tzw. wpływów klerykalnych do młodego pokolenia. Dzieci i młodzież, jak zauważał prymas, dawały jednak odważne świadectwo przynależności do Kościoła przez praktyki religijne, udział w liturgii, życiu sakramentalnym, katechizacji i rekolek$\operatorname{cjach}^{32}$.

W odpowiedzi na postanowienia ustawy, prymas mobilizował wiernych, by ich rodziny, domy stawały się kolebką katolickiego wychowania przyszłych pokoleń Polaków. Temat domowej edukacji religijnej i formacji katolickiej, podejmował podczas kazań i oficjalnych przemówien' ${ }^{33}$. Projekt powiązał z realizacją programu V roku Wielkiej Nowenny, przeżywanym pod hasłem „Rodzina Bogiem silna”34.

\section{Nauczanie religii}

Lata 1958-1961 to okres bezdekretowego usuwania religii ze szkół. Zapowiedź usunięcia nauki religii z systemu oświaty przyniosły obrady Komisji Wspólnej Rządu i Episkopatu z 31 VII 1958 r. Usunięcie ze szkół ponad dwóch tysięcy katechetów zakonnych na podstawie zarządzenia ministra oświaty z 1958 r. zdezorganizowało, a w wielu wypadkach przyczyniło się do faktycznej likwidacji katechezy szkolnej. Rok 1961 kończył okres bezdekretowego rugowania szkolnego nauczania religii. Przyniósł ustawodawstwo, które dało podstawę do usunięcia katechezy z systemu oświaty, w majestacie „prawa”. Kościół jednak zdążył wypracować alternatywne formy systematycznej formacji chrześcijańskiej, którą prowadzono w punktach katechetycznych, organizowanych w salkach parafialnych, domach zakonnych, czy mieszkaniach prywatnych. Władze państwowe szacowały, że w całym kraju działać będzie ok. 16000 punktów katechetycznych. Zamierzały opłacać z budżetu państwa zatrudnionych w nich katechetów. To pozornie korzystne pod względem finansowym rozwiązanie, budziło jednak podejrzenia przedstawi-

31 A. Mezglewski, H. Misztal, P. Stanisz, Prawo wyznaniowe, Warszawa 2011, s. 19-20.

32 AAG, S. Wyszyński, Pro memoria, 17 V 1961; 6 V 1961.

33 S. Wyszyński, Rodzice, nadeszła wasza godzina. Kazanie Prymasa Polski do rodziców katolickich, Frombork, 15 VIII 1961 r., w: idem, Dzieła zebrane..., op. cit., s. 326-334; idem, ,Rodzina Bogiem silna”. Kazanie Prymasa Polski ze szczytu Jasnej Góry do wiernych z całej Polski podczas odnowienia Ślubów Narodu, w piatym roku Wielkiej Nowenny, roku „Rodziny Bogiem silnej”, Jasna Góra, 26 VIII 1961, w: idem, Dzieła zebrane..., op. cit., s. 361-370.

34 Wielka Nowenna - ogólnopolski program duszpasterski 1957-1966, zainicjowany i opracowany przez prymasa Wyszyńskiego, w celu przygotowania Kościoła w Polsce do obchodów milenijnych. Szerzej zob. J. Żaryn, Dzieje Kościoła katolickiego w Polsce (1944-1989), Warszawa 2003, s. 218-225. 
cieli strony kościelnej. Stanowisko prymasa w tej sprawie było jednoznacznie negatywne. Przewidywał bowiem, że przez zapewnienie źródeł finansowania, państwo planuje uzależnić nauczanie religii pod względem organizacyjnym, kadrowym i programowym od władz świeckich ${ }^{35}$. Istotnie, strona państwowa przekazała hierarchii kościelnej następujące postulaty: a) organizacja punktów - tylko w pomieszczeniach kościelnych, nie w prywatnych; b) katecheci - tylko księża i świeccy, nie zakonnicy, uznani jako personel „sfanatyzowany", co de facto oznaczało, że wyróżniali się gorliwością, zaangażowaniem i dużym stopniem oddziaływania środowiskowego; c) stan sanitarny - oceniany przez władze świeckie; d) nałożenie obowiązku podpisania umowy przez proboszczów z władzami państwowymi; 5) nadzór - inspektorat szkolny. Biskup Choromański, po wizycie u Tadeusza Żabińskiego ${ }^{36}$, dyrektora Urzędu do Spraw Wyznań (UdsW) ${ }^{37}$, przekazał prymasowi do wiadomości zarządzenie ministerialne o nauczaniu religii w punktach katechetycznych ${ }^{38}$.

Prymas Wyszyński mobilizował do włączenia się w akcję katechizacyjną szeregi duchowieństwa diecezjalnego, osób zakonnych i świeckich ${ }^{39}$. Należy dodać, że prymas brał pod uwagę fakt, że nie należy narażać katolików świeckich na sankcje karne za udzielanie mieszkań prywatnych na punkty katechetyczne ${ }^{40}$.

Temat katechizacji był stale powracającym wątkiem w zapiskach prymasa w różnych aspektach i kontekstach. W Pro memoria odnotowywał fakty i wnioski z obrad Konferencji Plenarnej Episkopatu (KPE), podczas których biskupi poruszali temat katechizacji pozaszkolnej i roszczenia władz państwowych. Dzięki posiedzeniom, na których zbierali się biskupi ze wszystkich diecezji, prymas miał wgląd w ogólną sytuację panującą w całym kraju i poszczególnych diecezjach. W ramach struktur Episkopatu wykształciła się Komisja Katechetyczna. Z powodu likwidacji szkół wyznaniowych przez państwo, dotychczas działająca Komisja Szkolna KEP traciła rację bytu. Jej członkowie - zapisał prymas - zgłosili więc wniosek o reorganizację kierunku prac i przemianowanie komórki na Komisję Katechetyczną, która w ówczesnych warunkach była bardziej potrzebna ${ }^{41}$.

Ksiądz prymas interesował się powrotem ks. Jana Charytańskiego ${ }^{42}$ ze specjalistycznych studiów katechetycznych, odbywanych w Belgii. Ksiądz Charytański w przyszłości

\footnotetext{
35 AAG, S. Wyszyński, Pro memoria, 11 VIII $1961 \mathrm{r}$.

36 Tadeusz Żabiński (1904-1990), urzędnik państwowy, działacz PZPR, dyrektor UdsW 1961-1965.

37 Urząd do Spraw Wyznań (UdsW) - jednostka administracji państwowej powołana jako aparat kontroli i represji państwa wobec kościołów i związków wyznaniowych 1950-1989. UdsW posiadał agendy terenowe, tj. wydziały do spraw wyznań (WdsW) przy PRN.

38 AAG, S. Wyszyński, Pro memoria, 22 VIII 1961 r.

39 AAG, S. Wyszyński, Pro memoria, 19 I 1961 r.

40 AAG, S. Wyszyński, Pro memoria, 20 IX 1961 r.

41 AAG, S. Wyszyński, Pro memoria, 21 I 1961 r.; 1 IX 1961 r.

42 Jan Charytański SJ (1922-2009), ksiądz, teolog, katechetyk. Święcenia 1952. Doktorat z nauk teologicznych w zakresie katechetyki w 1966 r. Habilitacja 1972 r. Profesor nadzwyczajny 1977 r. Profesor zwyczajny
} 
zostanie wybitnym katechetykiem ${ }^{43}$. Prymas zabiegał o odpowiednie przygotowanie duchowieństwa do nauczania religii. W diecezjach organizowano kursy katechetyczne, w których duchowni brali liczny udział. Podczas szkoleń omawiano - jak to ujął ksiądz prymas - „ukaz” ministerialny o punktach katechetycznych. Zapoznawano księży ze strategią władz państwowych i reakcją biskupów. Wygłaszano referaty na tematy metodyczne, odnośnie pracy z dziećmi i młodzieżą. Prymas polecał zacieśniać więzi z rodzinami na terenie parafii, organizować specjalne nabożeństwa adresowane do młodzieży i rozwijać opiekę duszpasterską nad dziećmi ${ }^{44}$. Problem katechizacji podejmowany był podczas konferencji księży dziekanów ${ }^{45}$.

Z katechezy pozaszkolnej nie wycofywały się żeńskie zgromadzenia zakonne. Prymas interesował się założonymi z inicjatywy urszulanek unii rzymskiej zorganizowanymi formami kształcenia katechetycznego. Dzięki pracy ośrodków szkoleniowych, siostry zakonne, w zależności od stopnia wykształcenia, mogły podejmować naukę. Były to Wyższy Instytut Katechetyczny ${ }^{46}$ i Diecezjalny Instytut Katechetyczny ${ }^{47}$. Ośrodki utworzone zostały w Krakowie, a więc podlegały bezpośrednio pod jurysdykcję kościelną abp. Eugeniusza Baziaka ${ }^{48}$.

W zapiskach prymas Wyszyński wspominał, że temat katechizacji i wychowania katolickiego podjął podczas uroczystej sumy pontyfikalnej 26 VIII 1961 r. na Jasnej Górze: „Wygłaszam kazanie nt. «Rodzina Bogiem silna». Poruszam sprawę zamachu M[inistretswa] O[światy] na wolność nauczania w kościołach. [...] Plac zapełniają wielkie rzesze ludu". Uwrażliwiał na ten problem wiernych. Czuwał ponadto, aby wystosowany został odpowiedni list do władz rządowych, wyrażający protest Episkopatu wobec podjętych decyzji ${ }^{49}$.

Prymas stale uwrażliwiał rodziców, by dbali o katechizację swoich dzieci. Temat powracał podczas homilii, spotkań z rodzicami, zwłaszcza przy okazji wizytacji kanonicznych $\mathrm{w}$ parafiach ${ }^{50}$. W swoich zapiskach zwracał uwagę na wielkie poświęcenie ze strony

1983 r. Wykładowca na ATK i Bobolanum w Warszawie. Współtwórca Centrum Katechetycznego. Autor/ współautor ponad 150 publikacji, w tym podręczników do katechezy.

43 AAG, S. Wyszyński, Pro memoria, 10 VIII $1961 \mathrm{r}$.

44 AAG, S. Wyszyński, Pro memoria, 28 VIII 1961 r.

45 AAG, S. Wyszyński, Pro memoria, 9 XI 1961 r.

46 Wyższy Instytut Katechetyczny (WIK), zwany później Międzyzakonnym Wyższym Instytutem Katechetycznym (MWIK) - powołany przez kard. Adama Sapiehę w 1951 r. jako ośrodek przygotowania kadr katechetycznych i formacyjnych przeznaczony dla sióstr zakonnych, które uzyskały świadectwo dojrzałości. WIK utworzono na wniosek s. Emanueli Mrozowskiej OSU w Krakowie.

${ }^{47}$ Diecezjalny Instytut Katechetyczny (DIK) - powołany przez kard. Adama Sapiehę w 1950 r. w Krakowie, na wniosek s. Emanueli Mrozowskiej OSU, przy klasztorze sióstr urszulanek unii rzymskiej, jako ośrodek przygotowania kadr katechetycznych młodych sióstr zakonnych i kandydatek zgłaszających się do klasztorów. DIK posiadał internat międzyzakonny.

48 AAG, S. Wyszyński, Pro memoria, 11 IX 1961 r.

49 AAG, S. Wyszyński, Pro memoria, 26 VIII 1961 r.

50 AAG, S. Wyszyński, Pro memoria, 18 V 1961 r. 
dzieci, nawet najmłodszych, uczęszczających do klas początkowych szkoły podstawowej. Musiały bowiem podjąć spory wysiłek, aby uczestniczyć w katechizacji organizowanej poza szkołą. Przykładowo, dzieci komunijne w jednej z wiosek pokonać musiały odległość około $5 \mathrm{~km} \mathrm{z}$ domu do kościoła ${ }^{51}$. Odnotował jednak, że mimo ograniczeń i trudności, uczniowie masowo uczęszczali na lekcję religii, a wydarzeniom kościelnym towarzyszył „tłum” i to „niesamowity”, nawet w przypadkach, gdy lokalne władze świeckie organizowały wiele atrakcyjnych imprez, tylko po to, by „odciągnąć” młodzież od Kościoła i wydarzeń religijnych. Oceniał: Wróciła stara praktyka wywożenia młodzieży na czas przyjazdu biskupa ${ }^{52}$.

Prymas - na ile to było możliwe - wspierał miejscowe duszpasterstwo dzieci i młodzieży, wyrażając nim zainteresowanie. Przykładem mogą być parafialne konkursy katechetyczne. Prymas zauważał, że katechizowani brali w nich udział chętnie, a współzawodnictwo traktowali poważnie i z przejęciem. Patronat prymasa zapewne podnosił rangę tego typu rozgrywek ${ }^{53}$.

W związku z przegraną bitwą Kościoła stoczoną o obecność katechezy w szkole, prymas Wyszyński nie krył rozczarowania postawą katolików świeckich, zrzeszonych w Kole Poselskim „Znak” ${ }^{54}$. Liczył na większe z ich strony zaangażowanie w obronie spraw Kościoła. W ocenie hierarchy, posłowie zachowali się stosunkowo biernie, a nawet defensywnie. Prymas zapisat:

Wielka dyskusja nt. stuszności postulatów minimalnych ${ }^{55}$, wysuwanych przez dr. St [ommę] ${ }^{56}$. Dr St[omma] pragnie bronić Kościoła w ostatnim okopie, na płaszczyźnie zasad, od których już odstapić nie można. Wszystko inne opuszcza bez walki. Uważam tę metodę strategicznie i psychologicznie za błędna. Trzeba bronić Kościoła w pierwszym okopie, na płaszczyźnie słusznych postulatów Kościoła i ludzi wierzacych. Dopiero, gdy nie da się obronić pierwszej linii, można odstapić na druga, zawsze jednak podkreślając prawa Kościoła do pozycji, z której sita Kościót zostat wyparty. Zastrzegam się przeciwko temu minimalizmowi, który może być uważany przez przeciwnika za słabość lub też odstępstwo od prawdy. D[okto]ra St[ommy] przekonać nie można, gdyż jego program wyrasta z jego psychiki-

ubolewał ksiądz prymas $^{57}$.

51 AAG, S. Wyszyński, Pro memoria, 18 V 1961 r.

52 AAG, S. Wyszyński, Pro memoria, 21 V 1961 r.

53 AAG, S. Wyszyński, Pro memoria, 30 V 1961 r.

${ }^{54}$ Koło Poselskie „Znak” - środowisko działaczy katolickich związanych z czasopismami „Tygodnik Powszechny” i ,Znak”oraz KUL; kandydowali w wyborach do Sejmu PRL jako odrębna grupa.

55 Nawiązanie do koncepcji Stanisława Stommy, ogłoszonej w artykule pt. Maksymalne i minimalne tendencje społeczne katolików, który ukazał się na łamach „Znaku” 1946 r.

${ }^{56}$ Stanisław Stomma (1908-2005), prawnik, polityk, działacz katolicki. W latach 1957-1976 poseł na Sejm PRL z ramienia „Znaku”. Senator 1989-1991.

${ }^{57}$ AAG, S. Wyszyński, Pro memoria, 8 IX 1961 r. 


\section{Seminaria duchowne}

Ksiądz prymas dużo uwagi poświęcił sprawie seminariów duchownych ${ }^{58}$. Rzeczywiste intencje decydentów PRL w odniesieniu do formacji przyszłych duchownych, demaskował referat UdsW z 1961 r., który wskazywał, że państwo zmierza do przejęcia całkowitej kontroli nad seminarzystami, w celu kształtowania ich „,w duchu poszanowania władzy ludowej” oraz ,przekonań socjalistycznych”. Poddani indoktrynacji alumni, po przyjęciu święceń, zasilić mieli szeregi tzw. kleru postępowego, a w społecznościach lokalnych działać na rzecz legitymizacji systemu. Pierwsze seminaria duchowne objęto wizytacjami na początku 1960 r. Przedstawiciele władz kościelnych wystosowali w tej sprawie 17 XI 1960 list protestacyjny do rządu ${ }^{59}$. Episkopat wydał instrukcję dla rektorów seminariów, by nie wyrażali zgody na hospitację przedmiotów filozoficznych i teologicznych ${ }^{60}$. Na skargi Episkopatu odpowiedź nadesłał UdsW, dn. 23 I 1961. Roszczenia biskupów, co do jurysdykcji kościelnej nad seminariami, uznano za pozbawione podstaw prawnych.

W pro memoria prymasa Wyszyńskiego uwagę zwraca fakt, że Episkopat Polski często podejmował temat seminariów duchownych podczas spotkań z władzami państwowymi, przy czym rozmowy prowadzone były raz z inicjatywy władz państwowych, raz kościelnych. Pod koniec stycznia 1961 r. bp Choromański po wizycie u ministra Jerzego Sztachelskiego, dzielił się z prymasem spostrzeżeniami na temat reakcji ministra, uskarżającego się, że Episkopat wobec wizytacji państwowych w seminariach przyjął postawę oporu. Minister Sztachelski narzekał ponadto, że prymas osobiście angażował się w sporny problem. Biskup Choromański przekazał prymasowi, że złożył oświadczenie wobec ministra, że Episkopat nie godzi się na przejęcie nadzoru państwa nad seminariami ${ }^{61}$. Odwołał się do stanowiska prymasa Polski ${ }^{62}$. Choć w ocenie Kościoła, wizytacje urzędników ministerialnych przybierały „drastyczne formy”, minister Sztachelski twierdził, że nie ma powodów do niepokoju. Przebiegać miały rzekomo normalnie i spokojnie. Konfrontacji i negatywnym reakcjom na kontrole państwowe winny miał być Episkopat: To

${ }^{58}$ AAG, S. Wyszyński, Pro memoria, 3 II 1961 r.; 11 II 1961 r.; 13-14 XI 1961 r. i in.

59 Pierwsze działania władz podjęte celem objęcia seminariów duchownych kontrolą, przyniósł przełom lat 50. i 60 . Za podmioty kompetentne do sprawowania nadzoru nad seminariami duchownymi uznano Ministerstwo Oświaty oraz UdsW. Przeciw decyzji rządu kategorycznie zaprotestował Episkopat. M. Krawczyk, Urząd do spraw Wyznań a funkcjonowanie seminariów duchownych i służba wojskowa kleryków - studium historyczno- prawne, „Zeszyty Naukowe Uniwersytetu Przyrodniczo-Humanistycznego w Siedlcach. Seria: Administracja i Zarządzanie" 2016, nr 108, s. 32-35

${ }^{60}$ AAN, UdsW, 148/3, Episkopat a sprawa nadzoru nad seminariami, „Urząd do Spraw Wyznań. Informacje i materiały" (wyłącznie do użytku służbowego), styczeń 1961 r., k. 18; AAG, S. Wyszyński, Pro memoria, 24 I $1961 \mathrm{r}$.

${ }^{61}$ Chodzi o nadzór administracyjny i pedagogiczny. Decyzje w sprawach zarządu, obsady personalnej, programu nauczania i wychowania w seminariach duchownych należały do kompetencji władz kościelnych.

${ }^{62}$ AAG, S. Wyszyński, Pro memoria, 24 I 1961 r. 
tylko biskupi się denerwują, to tylko prymas niepotrzebnie naraża swój autorytet ${ }^{63}$. Prymas odnotował, że ks. Józef Pacyna ${ }^{64}$, rektor Arcybiskupiego Seminarium Duchownego w Gnieźnie, który nie zgodził się na wizytację biblioteki seminaryjnej, miał z tego tytułu problemy z władzami. Ostatecznie został jednak „uniewinniony” przez prokuratora, bo jego zachowanie oceniono w kategoriach „znikomego niebezpieczeństwa społecznego"65.

Minister Sztachelski domagał się zgody biskupów na wizytację przedmiotów teologicznych. Uważał, że wprowadzanie rozróżnień między przedmiotami, które objęte miały zostać kontrolą, świadczyło o braku zaufania strony kościelnej do kompetencji wizytatorów ministerialnych. Biskup Choromański relacjonował prymasowi swoją odpowiedź na zarzuty, w której stwierdził, że wizytatorzy sami się właściwie zdyskwalifikowali, bo zaczęli [wizytować seminaria] od kuchni i spraw sanitarnych. W lutym minister Sztachelski skarżył się na Metropolitalne Wyższe Seminarium Duchowne w Warszawie, gdzie nie udało się przeprowadzić wizytacji. Tłumaczył, że UdsW rzekomo bronił seminarium przed konsekwencjami, których domagało się kuratorium okręgu szkolnego warszawskiego. Z tego tytułu miał żal, że władze seminaryjne nie potrafiły docenić gestu, a dodatkowo w sprawę osobiście zaangażował się prymas. Ksiądz prymas podsumował: Nie wie p. Sz[tachelski], że biskup bez seminarium jest jak bez źrenicy oko ${ }^{66}$.

Wizytacje państwowe były kontynuowane ${ }^{67}$. W 1961 r. na ogólną liczbę 103 seminariów wizytacjami państwowymi objęto 77, w tym wyższych seminariów duchownych diecezjalnych 19, zakonnych 29, a niższych seminariów duchownych 20 . W roku szkolnym 1961/1962 większość władz seminaryjnych podporządkowała się zarządzeniom władz państwowych, a wizytacje odbywały się bez większych zakłóceń. Sprzeciwiano się natomiast, wizytacjom przedmiotów o charakterze teologicznym ${ }^{68}$. Prymas monitorował sytuację w całym kraju i wydawał stosowne zalecenia. Podczas obrad KPE relacjonowano, że władze państwowe nadal podejmowały próby ingerencji w pracę seminariów. Usiłowano wchodzić na wykłady wbrew woli rektora, jak na przykład w Opolu, czy Lublinie $^{69}$.

W przypadku braku zgody rektora na kontrolę zewnętrzną, władze partyjno-państwowe stosowały środki odwetowe, jak pobór alumnów do wojska, co dezorganizowało pracę seminariów. W maju 1961 r. UdsW wydał okólnik adresowany do wojewódzkiej administracji wyznaniowej, celem usprawnienia poboru głównego w $1961 \mathrm{r}^{70}$ Seminaria,

${ }^{63}$ AAG, S. Wyszyński, Pro memoria, 3 II 1961 r.

64 Józef Pacyna (1906-1985), ksiądz, doktor teologii, rektor PWSD w Gnieźnie 1947-1963.

${ }_{65}$ AAG, S. Wyszyński, Pro memoria, 4 I 1961 r.

${ }^{66}$ AAG, S. Wyszyński, Pro memoria, 11 II 1961 r.

${ }^{67}$ AAN, UdsW, 148/3, Wizytacje seminariów duchownych, „Urząd do Spraw Wyznań. Informacje i materiały" (wyłącznie do użytku służbowego), luty 1961, k. 49.

${ }^{68}$ M. Krawczyk, op. cit., s. 32-35.

${ }^{69}$ AAG, S. Wyszyński, Pro memoria, 16 III 1961 r.

${ }^{70}$ M. Krawczyk, op. cit., s. 44. 
które okazywały stosunkowo dużą spolegliwość wobec żądań władz świeckich - jak zauważył prymas - nie uniknęły różnego typu represji. Podsumowywał: wizytacje traktowane sa różnie; tam, gdzie częściowo dopuszczono wizytację, też powoływano do wojska, czego nie czyniono często tam, gdzie nie dopuszczono wizytacji. Należy usztywnić obronę seminariów ${ }^{71}$.

Klerykom, których władze skierowały do odbycia służby wojskowej, prymas polecił wykorzystać pobyt $\mathrm{w}$ jednostkach wojskowych jako miejsce posługi duszpasterskiej. Zapisał: w swoim przemówieniu mówitem o tym, że w wojsku też sq dusze, odkupione krwiq Chrystusa. Klerycy kieleccy wracaja z wojska mocno wprowadzeni w prace apostolska ${ }^{72}$. Jednocześnie, na rzecz zwolnienia kleryków, podejmował interwencje w $\mathrm{MON}^{73}$ i UdsW ${ }^{74}$. Interwencje i podania Episkopatu zasadniczo nie były rozpatrywane pozytywnie. Nie pozostawały jednak bez echa, a zdarzało się, że przynosiły efekty częściowe. Przykładowo, bp. Lucjan Bernacki ${ }^{75}$, który odbył spotkanie z Edwardem Kędzierskim, kierownikiem Wydziału do Spraw Wyznań w Poznaniu, przekazał prymasowi, że spotkał się z jednej strony z ubolewaniem Kędzierskiego, że ksiądz prymas nie pofatygował się osobiście do niego. $Z$ drugiej strony kierownik doceniał fakt, że prymas wystosował oficjalne pismo. Postawę uznał za przejaw „liczenia” się z władzami państwowymi. Dlatego „władza” podjęła decyzję o zwolnieniu z wojska alumnów V i VI kursu. Pozostali natomiast mieli pozostać $\mathrm{w}$ jednostkach ${ }^{76}$.

Kościół zmagał się ponadto z akcją likwidacji niższych seminariów duchownych, zapoczątkowaną decyzją Biura Politycznego KC PZPR z $1960 \mathrm{r}^{77}$. Dyrektor seminarium na warszawskiej Pradze, Adam Hofman ${ }^{78}$, relacjonował prymasowi sprawę opieczętowania gmachu seminaryjnego ${ }^{79}$. Dekrety o zabezpieczeniu lokalu wydano 4 sierpnia, a zarządzenie o zamknięciu szkoły 8 sierpnia, z 14-dniowym terminem na odwołanie ${ }^{80}$. Likwidacji nie zatrzymał protest Episkopatu wyrażony w liście do Urzędu Rady Ministrów z 17 VIII $1961^{81}$. Likwidację poprzedziły wizytacje świeckie, które wykazać miały niski

${ }^{71}$ AAG, S. Wyszyński, Pro memoria, 15 XI $1961 \mathrm{r}$.

72 AAG, S. Wyszyński, Pro memoria, 25 III 1961 r.

${ }^{73}$ AAG, S. Wyszyński, Pro memoria, 1 X 1961 r.

${ }^{74}$ AAG, S. Wyszyński, Pro memoria, 29 IX 1961 r.; 30 IX 1961 r.; 28 X 1961 r.

${ }^{75}$ Lucjan Bernacki (1902-1975), biskup pomocniczy gnieźnieński 1946-1975, wikariusz generalny i kapitulny archidiecezji gnieźnieńskiej od $1948 \mathrm{r}$.

${ }^{76}$ AAG, S. Wyszyński, Pro memoria, 28 X 1961 r.

${ }^{77}$ AAG, S. Wyszyński, 10 VIII 1961 r., 12 VIII 1961 r., 22 VIII 1961 r.

${ }^{78}$ Adam Hofman (1911-1964), ksiądz, doktor filozofii, dyrektor Niższego Seminarium Duchownego w Warszawie.

${ }^{79}$ AAG, S. Wyszyński, Pro memoria, 10 VIII 1961 r.

${ }^{80}$ AAG, S. Wyszyński, Pro memoria, 11 VIII 1961 r.

${ }^{81}$ M. Krawczyk, op. cit., s. 41. 
poziom nauczania i niewłaściwy kierunek wychowawczy placówek ${ }^{82}$. Prymas odnotował, że kuratorium rozsyłało do rodziców uczniów zaproszenie, petne troski o przysztość chłopców, oferując im pomoc w umieszczeniu w innych szkołach oraz wsparcie stypendialne. Chytra robota, byle tylko odciagnać ludzi z drogi powołania kapłańskiego - oceniał prymas ${ }^{83}$.

\section{Instytucje opiekuńczo-wychowawcze i szkolnictwo konfesyjne}

Antyzakonna polityka wyznaniowa władz komunistycznych zmierzała do całkowitego odsunięcia osób zakonnych z edukacji. Siostry zakonne miały zostać pozbawione wpływu na wychowanie dzieci i młodzieży, stąd przesuwano je do pracy w zakładach specjalnych i domach opieki dla osób w podeszłym wieku. Często były to placówki niedofinansowane, do których obsługi trudno było znaleźć personel. Siostry przekwalifikować się miały na prowadzenie zakładów dla dzieci upośledzonych. Prymas odnotował wizytę w tego typu zakładzie, prowadzonym przez siostry dominikanki w Mielżynie ${ }^{84}$ :

Dzieci sa specjalnie wybrane ${ }^{85}$, najcięższe przypadki, przeważnie na tle alkoholowym rodziców. Sa tu dzieci m.in. dygnitarzy dzisiejszych. Zakład urządzony jest wzorowo i estetycznie; duzo zieleni, kwiatów, pogody w salach, zabawek. Ale obraz dzieci jest bolesny. To wszystko sq ofiary skazane na dożywotnie więzienie $w$ złotej klatce. Wrażenie wprost straszne; trudno mówić o wspótczuciu, gdyż usta się zamykają. Wychodzę stąd niemal chory ${ }^{86}$.

Do księdza prymasa zgłaszały się przełożone wyższe zgromadzeń zakonnych, z zapytaniem odnośnie postępowania w przypadkach, gdy władze państwowe polecały im zreorganizować dotychczasową działalność, np. w domach dziecka, tzn. przekształcać istniejące placówki na zakłady dla dzieci upośledzonych, w celu uchronienia własności zakonnej przed upaństwowieniem. Prymas radził: Uważam, że nie należy przyspieszać tego procesu. Zawsze jeszcze można coś dobrego zrobić dla normalnych ludzi ${ }^{87}$.

Podczas KPE - odnotował prymas - omawiano sytuację pozostałych jeszcze szkół katolickich, które wbrew porozumieniu między państwem a Kościołem przeznaczano stopniowo do likwidacji. Biskupi relacjonowali sytuację na tym polu, panującą w zarzą-

82 Archiwum Państwowe w Warszawie, Prezydium Wojewódzkiej Rady Narodowej Wydziału do Spraw Wyznań, 14, F. Nitka, T. Żabiński, Sprawozdanie z wizytacji NSD oo. franciszkanów w Niepokalanowie przeprowadzonej 7 II 1961, Warszawa, 14 III 1961, k. 15.

${ }^{83}$ AAG, S. Wyszyński, Pro memoria, 22 VIII 1961 r.

${ }^{84}$ Chodzi o zakład prowadzony przez siostry dominikanki. Do 1952 r. siostry prowadziły dom dziecka. Władze państwowe odebrały im podopiecznych w 1952 r. Na miejsce sierot sprowadzono ok. 100 dzieci specjalnej troski.

${ }^{85}$ Chodzi o decyzję władz świeckich.

${ }^{86}$ AAG, S. Wyszyński, Pro memoria, 5 I 1961 r.

87 AAG, S. Wyszyński, Pro memoria, 13 IX 1961 r. 
dzanych przez nich diecezjach. Przykładowo bp Zdzisław Goliński ${ }^{88}$ przedstawił fakty dotyczące upaństwowienia szkół sióstr nazaretanek w Częstochowie ${ }^{89}$. Na bezprawne akty prymas polecał reagować. W tej konkretnej sytuacji bp Choromański wystąpić miał z pismem do rządu i zwrócić uwagę na naruszenie porozumienia między rządem a Episkopatem $^{90}$.

Prymas zapisał krótką relację ze spotkania z siostrami niepokalankami z Szymanowa, które opowiadały o kłopotach z prowadzoną przez nie szkołą: Wizytatorzy wrogo usposobieni do szkoły, odmówili praw ${ }^{91}$. Na interwencji nie zależało posłowi katolickiemu, Jerzemu Zawieyskiemu ${ }^{92}$. Prymas radził siostrom, by „uruchomiły” rodziców uczennic ${ }^{93}$.

Ksiądz prymas wspominał fakty upaństwawiania przedszkoli zakonnych i parafialnych. Zapisywał, jak stawiały się u niego przełożone wyższe zgromadzeń zakonnych, informując o likwidacji prowadzonych przez siostry przedszkoli ${ }^{4}$. Odnotował swój pobyt u sióstr szarytek, których dom główny przejęty został częściowo na przedszkole państwowe. Przy okazji prymas Wyszyński odwiedzał dzieci w działających jeszcze przedszkolach wyznaniowych ${ }^{95}$.

Podczas KPE na Jasnej Górze, o złożenie wizyty prymasowi ubiegały się rodzone siostry prezydenta USA ${ }^{96}$. Prymas uznał, że spotkanie obliczone było na rozgłos medialny, czego wolał uniknąć. Nadto, w tym czasie w Częstochowie kordony milicji otoczyły dom sióstr nazaretanek, likwidując przedszkole i szkotę. W takiej sytuacji ważniejsze sa siostry nazaretanki, niz siostry prezydenta Kennedy['ego] - stwierdzał" ${ }^{97}$.

88 Zdzisław Goliński (1908-1963), biskup częstochowski 1951-1963, doktor habilitowany teologii.

8930 VIII 1961 decyzją ministra oświaty pozbawioną podstaw prawnych, państwo przejęło bez odszkodowania liceum sióstr nazaretanek w Częstochowie, tj. obiekt składający się z 27 pomieszczeń wraz z wyposażeniem, podwórko i ogród. Przy okazji upaństwowienia szkoły, zlikwidowano działające tam przedszkole zakonne. 26 sióstr nazaretanek zostało pozbawionych pracy i środków do życia.

90 AAG, S. Wyszyński, Pro memoria, 1 IX 1961 r.

91 Szkoła sióstr niepokalanek w Szymanowie - założona jako placówka szkolno-wychowawcza w 1907 r. Uroczyście otwarta jako liceum z internatem w 1908 r. Podczas II wojny światowej miejsce tajnego nauczania i schronienie dla ludności cywilnej, w tym Żydów. Po wojnie nieustannie zagrożona w istnieniu. Siostry nękane uciążliwymi wizytacjami uczyły w częściowej konspiracji. Stosowały podwójny plan lekcji. Oficjalny obowiązywał wobec wizytatorów państwowych. Według wewnętrznego prowadzono zajęcia na co dzień. Mimo represji, szkoła przetrwała.

92 Jerzy Zawieyski (1902-1969), działacz katolicki, prezes warszawskiego KIK od 1957 r., polityk, członek Rady Państwa 1957-1968, poseł „Znaku” 1957-1969, wiceprezes ZLP 1947-1969, redaktor „Tygodnika Powszechnego" 1946-1953 i od $1956 \mathrm{r}$.

93 AAG, S. Wyszyński, Pro memoria, 1 III 1961 r.

${ }^{94}$ AAG, S. Wyszyński, Pro memoria, 13 IX 1961 r.

95 AAG, S. Wyszyński, Pro memoria, 21 V 1961 r.

${ }_{96}$ Na początku września 1961 r. na kilka dni przyjechały do Polski siostry prezydenta USA Johna Kennedy’ego: Eunice Kennedy Shriver i Jean Kennedy Smith. Na trasie ich podróży znalazły się: Zakopane, Kraków, Częstochowa i Warszawa.

${ }^{97}$ AAG, S. Wyszyński, Pro memoria, 4 IX 1961 r. 
Zwracał uwagę na reakcje społeczne towarzyszące upaństwawianiu placówek wyznaniowych: W Kutnie władze państwowe gwałtem przejęty przedszkole „Caritas" "98, chcac też zabrać i dom katolicki. Matki stanęty w obronie przedszkola. Wytworzyła się wielka awantura. Rezultat - wszczęcie postępowania administracyjnego przeciwko księżom kutnowskim. Przytaczał fakty, jak siostry wyrzucane były przez przedstawicieli władz państwowych z własnych domów ${ }^{99}$.

Prymasowi zależało na utrzymaniu szkół konfesyjnych. Interesował się ich rozwojem, możliwościami podnoszenia kwalifikacji przez zatrudniony w nich personel. Odnotował starania franciszkanek służebnic krzyża, opiekujących się niewidomymi podopiecznymi w zakładzie w Laskach ${ }^{100}$.

\section{Szkolnictwo wyższe}

Osobne zagadnienie stanowiło wyznaniowe szkolnictwo wyższe. Do najważniejszych tematów pojawiających się w pro memoria prymasa Wyszyńskiego zaliczyć w tym obszarze należy: Katolicki Uniwersytet Lubelski (KUL), Akademia Teologii Katolickiej w Warszawie oraz duszpasterstwo akademickie, zwłaszcza pielgrzymka studentów na Jasną Górę.

KUL mimo represji w postaci: wygórowanych podatków, nakładanych grzywien, zamykania kierunków i blokowania awansów, rozwijał się, jakby na przekór władzom państwowym ${ }^{101}$. Wiadomości z działalności i sytuacji uczelni referowane były biskupom przez ordynariusza lubelskiego, bp. Piotra Kałwę ${ }^{102}$, podczas KPE ${ }^{103}$. Prymas Wyszyński odnotował ponadto spotkania z ks. Marianem Rechowiczem ${ }^{104}$, rektorem KUL. Podejmowane w rozmowach wątki dotyczyły głównie odniesień władz państwowych do uczelni i ich skutków, przede wszystkim sankcji ekonomicznych oraz problemów kadrowych. W przypadku roszczeń ekonomicznych, prymas Wyszyński radził zachować daleko idącą ostrożność. Priorytetem działalności KUL zarówno tym rzeczywistym, jak i prezentowanym na zewnątrz miały być zawsze sprawy wartości wyższych - intelektualne i ogólnoformacyjne. Egzekwowanie należnych uczelni praw nie mogło koncentrować się wokół kwestii materialnych - podkreślał ksiądz prymas. Nie oznaczało to jednak, że rezygno-

${ }_{98}$ Przedszkole w Kutnie przy ul. Kościuszki 1, prowadziły siostry franciszkanki Rodziny Maryi.

99 AAG, S. Wyszyński, Pro memoria, 16 IX 1961 r.

100 AAG, S. Wyszyński, Pro memoria, 8 V 1961 r.

101 AAG, S. Wyszyński, Pro memoria, 27 I 1961 r.; 26 V 1961 r.; 30 V 1961 r.; 9 VIII 1961 r.

102 Piotr Kałwa (1893-1974), biskup lubelski od 1949 r. Członek Rady Głównej KEP.

103 AAG, S. Wyszyński, Pro memoria, 12 I 1961 r.

${ }_{104}$ Marian Rechowicz (1910-1983), ksiądz, historyk kościoła, profesor zwyczajny teologii, rektor KUL 1956-1965. W latach 1967-1973 kierownik Instytutu Historii Kościoła KUL. Od 1974 r. biskup. Od 1979 r. przewodniczący Rady Naukowej KEP. 
wał z walki o podstawy materialne dalszego bytu katolickiej uczelni. Chodziło mu przede wszystkim o zachowanie właściwej hierarchii spraw ${ }^{105}$.

Księdzu rektorowi Rechowiczowi polecił stać na stanowisku niepłacenia podatków dochodowych, tłumacząc, że KUL nie był „przedsiębiorstwem dochodowym”. Dodawał, że należy bronić uczelnię przed grożącym jej 65\% opodatkowaniem stołówek akademickich. Podkreślał: KUL dba nie tylko o sprawy naukowe, ale $i$ - bytowe profesorów i mtodzieży, co jest historycznym dorobkiem uniwersytetów $w$ ogóle ${ }^{106}$. Prymas Wyszyński powiadamiany był o rewizjach przeprowadzanych przez przedstawicieli władz świeckich w konwikcie KUL ${ }^{107}$. W sprawach kadrowych ubolewał: Rozkłada się ludzi pracujacych na KUL. Nie zatrzymywał się jednak na trudnościach. Poruszał tematy związane z rozwojem naukowej refleksji teologicznej, zwłaszcza w kontekście przygotowań do Vaticanum II, m.in. ekumenizmu i eklezjologii w kontekście dialogu międzywyznaniowego ${ }^{108}$.

Prymas odnotował spostrzeżenia księdza rektora Rechowicza na temat zaostrzającego się stosunku UMCS do KUL ${ }^{109}$. Przy okazji omawiania spraw KUL i UMCS ${ }^{110}$, warto wspomnieć, że w zapiskach pozostał interesujący zarys portretu osobowościowego pedagog specjalnej, Zofii Sękowskiej ${ }^{111}$. Po uzyskaniu dyplomu doktorskiego na Uniwersytecie Warszawskim (UW) złożyła wizytę księdzu prymasowi. Sękowska prywatnie była żoną Modesta ${ }^{12}$, ociemniałego kierownika spółdzielni dla niewidomych w Lublinie oraz matką czterech synów. Prymas wspominał:

Prawdziwie mulier fortis ${ }^{113} w$ drobnym ciele. Tej kobiecie należy się kilka stów. Należała początkowo do zespołu „Ósemki”. W czasie studiów na KUL pomagała ociemniatemu studentowi, Modestowi Sękowskiemu, wychowankowi Lasek, którego uczytem w szkole zawodowej. Sękowski zdobyt maturę przy pomocy Zofii, która później była lektorka jego, w czasie studiów Modesta na KUL. Dzięki niej Sękowski skończyt KUL. Powodowana współczuciem dla ociemniałego, Zofia przyjęła jego propozycję małzeństwa. Znajac styl estetyczny Zofii byłem temu przeciwny. Bałem się resentymentów młodej dziewczyny, które wobec realizmu pożycia z ociemniałym, moga się spotęgować. Przewidywania te okazały się stuszne. Ale Zofia dzielnie sobie

105 AAG, S. Wyszyński, Pro memoria, 9 VIII 1961 r.

106 AAG, S. Wyszyński, Pro memoria, 29 XI 1961 r.

107 AAG, S. Wyszyński, Pro memoria, 9 VIII 1961 r.

108 AAG, S. Wyszyński, Pro memoria, 27 I 1961 r.

109 AAG, S. Wyszyński, Pro memoria, 10 X 1961 r.

${ }^{110} \mathrm{Na}$ temat sytuacji na KUL i UMCS szerzej zob. D. Gałaszewska-Chilczuk, „, Wrogie” uniwersytety. Polityka państwa komunistycznego wobec Katolickiego Uniwersytetu Lubelskiego i Uniwersytetu Marii Curie-Skłodowskiej (1944-1969), Warszawa 2013.

111 Zofia Sękowska (1924-1997), pedagog specjalny, doktor nauk humanistycznych. Wykładowca na KUL do 1966 r. Habilitacja 1969 r. Docent na UMCS 1970-1977. Kierownik Zakładu Psychopedagogiki Specjalnej 1970-1991. Dziekan Wydziału Pedagogiki i Psychologii UMCS 1981-1982. Profesor zwyczajny od 1987 r. Twórczyni lubelskiej szkoły pedagogiki specjalnej. Członkini i ekspert regionu NZSS „Solidarność”.

112 Modest Sękowski (1920-1972), działacz społeczny. Założyciel, a następnie prezes Lubelskiej Spółdzielni Inwalidów Niewidomych. Członek WRN w Lublinie 1958-1966.

113 Łac. kobieta silna, mocna. 
poradziła, dzięki swej głębokiej wierze i nadprzyrodzonej wrażliwości. I dziś jest niełatwo, ale moc Boża zwycięża. Zofia po skończeniu KUL-u zaczęła pracować jako siła naukowa przy katedrze pedagogiki specjalnej. Ma dziś czterech synów, a właściwie pięciu, bo i ociemniatego męża. Pomimo wszystko zdobyta doktorat, pod kierunkiem prof. Grzegorzewskiej ${ }^{114}$ z Uniw [ersytetu] Warszawskiego. Ma dziś wątpliwości, co dalej robić, czy pracować naukowo, robić habilitację, czy oddać się wychowaniu dzieci. Na KUL brak poparcia. Ma ofertę od UMCS, by tam się habilitować. Znając jej delikatna psychikę radzę, by jednak pozostała na KUL i starata się przezwyciężyć nieprzychylna dla niej atmosferę $e^{115}$.

Pro memoria z 1961 r. ukazują ponadto starania i wysiłki prymasa, w celu nadania ATK oblicza faktycznie katolickiego ${ }^{116}$. Wśród pracowników naukowych i pozanaukowych uczelni znaleźli się tzw. księża postępowi, związani ze środowiskiem PAX $^{117}$ i niepodporządkowani hierarchii kościelnej. Prymas niepokoił się, że na ATK wykładał ks. Stanisław Huet ${ }^{118}$, a dyrektorem biblioteki ATK pozostawał ks. Czesław Borawski119. Prymas zdecydowanie sprzeciwiał się ich zatrudnieniu. Stwierdzał: Ponieważ ATK nie wypetniło dotychczas warunków, więc i ja będę zwlekał z dalszymi działaniami na rzecz $A T K^{120}$. Sprawy tzw. księży patriotów powracały w rozmowie prymasa Wyszyńskiego z rektorem ATK. Podczas rozmów prymas Wyszyński zwracał uwagę, że nominacje wspomnianych księży nie były kanoniczne, a w praktyce zdecydował o nich dyrektor UdsW, wbrew woli biskupa ${ }^{121}$.

Pozostawione w zapiskach ślady wskazują, że prymas Wyszyński pomimo trudnych relacji, starał się budować i podtrzymać więź z ATK, uczelnią, która działała pod silnym nadzorem władz państwowych. Prymas odnotował odwiedziny w konwikcie teologicznym ATK, spotkania z profesorami. Do środowiska akademickiego wygłosił konferencję, wysłuchał przemówienia ks. rektora Wincentego Kwiatkowskiego ${ }^{122}$ i innych prelegen-

114 Maria Grzegorzewska (1888-1967), pedagog, twórczyni polskiej pedagogiki specjalnej. Dyrektorka Państwowego Instytutu Pedagogiki Specjalnej (obecnie Akademia Pedagogiki Specjalnej im. Marii Grzegorzewskiej).

115 AAG, S. Wyszyński, Pro memoria, 4 IV 1961 r.

116 AAG, S. Wyszyński, Pro memoria, 3 III 1961 r.

117 Stowarzyszenie PAX - organizacja katolików świeckich działająca w latach 1952-1993. Założona przez przedstawicieli środowiska kierowanego przez Bolesława Piaseckiego. Prowadziła działalność lojalną wobec władz komunistycznych. Zmierzała do włączenia katolików w propagandę i budowę ustroju socjalistycznego w Polsce.

118 Stanisław Huet (1904-1961), ksiądz z diecezji lwowskiej, teolog. Wykładowca i prodziekan Wydziału Teologii Katolickiej UW od 1949 r. Profesor nadzwyczajny UW od 1953 r. Wykładowca na ATK od 1954 r. Związany ze Stowarzyszeniem PAX. W latach 1953-1956 narzucony Kościołowi przez władze komunistyczne jako wikariusz generalny archidiecezji krakowskiej.

119 Czesław Borawski, ksiądz, dyrektor biblioteki ATK 1956-1961. Związany ze środowiskiem tzw. księży patriotów.

120 AAG, S. Wyszyński, Pro memoria, 3 III 1961 r.

121 AAG, S. Wyszyński, Pro memoria, 9 VI 1961 r.

122 Wincenty Kwiatkowski (1892-1972), ksiądz, profesor zwyczajny teologii, rektor ATK 1956-1965. Związany z ruchem tzw. księży patriotów. Twórca warszawskiej szkoły apologetycznej. 
tów, a także prezesa studentów. Prymas podejmował zagadnienia dotyczące związków wiary z intelektem (fides quaerens intellectum) ${ }^{123}$. Po części teoretycznej, naukowej wydarzenia, prymas udał się - jak wspominał - na spotkanie ze wszystkimi profesorami w rektoracie. Wizytę w ATK podsumował: Dążę do tego, by podnieść poziom kościelny profesorów, poprawić dobór stuchaczy, a przez to stworzyć lepsze warunki do ukanonicznienia ATK, w przysztości, gdy na to pozwola warunki ${ }^{124}$.

\section{Duszpasterstwo akademickie}

Odrębne zagadnienie stanowi duszpasterstwo akademickie. Do prymasa Wyszyńskiego - jak zanotował - zgłaszali się księża zaangażowani w pracę ze studentami. Naradzali się w sprawie trudności napotykanych na polu posługi duszpasterskiej ${ }^{125}$, wśród nich ksiądz prymas wymienił imiennie m.in. ks. Józefa Gniewniaka ${ }^{126}$.

Władze państwowe wyrażały zaniepokojenie systematycznymi spotkaniami młodzieży w ramach duszpasterstwa, a także wpływem księży na studentów, organizowanymi przez księży masowymi wydarzeniami religijnymi, zwłaszcza ruchem pątniczym. Biskup Choromański relacjonował prymasowi rozmowę, którą w tej sprawie odbył z ministrem Jerzym Sztachelskim w UdsW. Minister „w tonie łagodnym” ostrzegać miał, że pielgrzymka akademicka stanowi zbyt poważne ryzyko, ponieważ przekształcić się może w wydarzenie o charakterze ,antykomunistycznym” i , ,antyżydowskim”'127.

Prymas Wyszyński zdecydowanie popierał organizację pielgrzymki akademickiej. Sprawę tę jednak konsultował z szerokim kręgiem zainteresowanego duchowieństwa biskupami oraz duszpasterzami akademickimi. Przykładowo księża jezuici Tomasz Rostworowski ${ }^{128}$ i Józef Majkowski ${ }^{129} \mathrm{z}$ obawy przed represjami proponowali odwołanie pielgrzymki. Z kolei ks. Mieczysław Jabłonka ${ }^{130}$ i ks. Tadeusz Kozłowski ${ }^{131}$, opowiadali

123 Łac. wiara szuka zrozumienia.

124 AAG, S. Wyszyński, Pro memoria, 5 XII 1961 r.

125 AAG, S. Wyszyński, Pro memoria, 17 I 1961 r.

126 Józef Gniewniak (1922-2000), ksiądz, duszpasterz akademicki w parafii św. Jakuba w Warszawie, katecheta klas licealnych w latach 1957-1973.

127 AAG, S. Wyszyński, Pro memoria, 8 V 1961 r.

128 Tomasz Rostworowski SJ (1904-1974), ksiądz, doktor teologii, muzykolog, ceniony rekolekcjonista. Duszpasterz środowisk akademickich oraz inteligencji katolickiej w Łodzi i Lublinie 1957-1963. W latach 1967-1974 kierownik polskiej sekcji Radia Watykańskiego.

129 Józef Majkowski SJ (1915-1987), duszpasterz akademicki przy kościele św. Andrzeja Boboli w Warszawie. Od 1980 r. członek kościelnej redakcji transmisji Mszy św. przez Polskie Radio.

130 Mieczysław Jabłonka (1914-1986), ksiądz, przewodniczący archidiecezjalnej komisji ds. duszpasterstwa akademickiego, członek kolegium wydziału ds. duszpasterstwa i komisji duszpasterstwa specjalnego.

131 Tadeusz Kozłowski (1923-2000), ksiądz, duszpasterz w Akademickim Kościele św. Anny w Warszawie. Członek archidiecezjalnej komisji duszpasterstwa akademickiego. Wizytator nauki religii. 
się za jej utrzymaniem. Ostatecznie prymas podjął decyzję, że pielgrzymka odbędzie się, choćby przybyło kilku akademików, jak to było w czasie okupacji niemieckiej ${ }^{132}$. Zanotował jednak, że sam na pielgrzymkę udał się nie bez obaw. Przed wyjazdem docierały do niego bowiem informacje odnośnie zachowania przedstawicieli władz świeckich wobec studentów, uczestników pielgrzymki. Podejmowane działania prymas uznał za terror. Rektorzy zobowiązani zostali do relegowania uczestników pielgrzymki, zintensyfikowano propagandę prasową, którą prymas nazwał „komunistyczną”, nasilono kontrole. Młodzież nachodzona była ponadto w domach prywatnych i ostrzegana przed konsekwencjami udziału w pielgrzymce. Prymas oceniał, że psychoza, lęk i zastraszenie stawały się coraz bardziej wyczuwalne ${ }^{133}$.

Ostatecznie zwycięstwo odniosły oddziaływania wychowawcze i autorytet Kościoła. Panującą atmosferę oddają słowa prymasa Wyszyńskiego:

W kaplicy Matki Bożej odprawiam Mszę św. Młodzieży jest już dużo. Stoi cicho i modli się. Sa obawy, że nie dopiszą. [...] Młodzież wypetnia szczelnie cała główna nawę, aż do wieży, i boczna, prawa. Jest ich więcej, niż przypuszczaliśmy. Gdy szedtem na ambone, przechodziłem przez zwarta ciżbę. Jeden z księży mówi mi, że wywiadowców z aparatami jest petno na watach. Pyta się, czy by ich nie zdemaskować? Odpowiadam: lepiej ich nie zauważać - róbmy swoje. Z ambony widok wspaniaty: głowa przy głowie, jest ciasno, tłoczno, duszno. Przemawiam [...]. Trwa to trzy kwadranse; sluchacze stoja w milczeniu. Następuje odnowienie ślubowań. Wszystka młodzież posiada maszynopisy ślubowań. [...] Ślubowanie robi potężne wrażenie. Odśpiewujemy Apel Jasnogórski. Jeszcze My chcemy Boga i młodzież powoli wychodzi. O[jcowie] paulini przygotowali dla nich ,zawiesista zupę” $w$ dwóch stołówkach i na wirydarzu klasztornym. Dochodza stamtąd śpiewy młodzieńcze. Wszyscy jesteśmy zdumieni, skąd się ta młodzież wzięta. Przecież legitymowano ich $w$ biegnacych pociagach, przy wyjściu, na ulicach. Terror w najwyższym wymiarze ${ }^{134}$.

Podsumowując, w pro memoria prymasa Wyszyńskiego z 1961 r. wyeksponowany został problem polityki oświatowej państwa w kontekście Ustawy o rozwoju systemu oświaty i wychowania z 15 VII 1961 r. Uwaga autora zapisków koncentrowała się szczególnie wokół sprawy nauczania religii, seminariów duchownych, średniego szkolnictwa wyznaniowego i szkolnictwa wyższego. Zadekretowana ustawą świeckość nauczania i wychowania nie oznaczała przy tym neutralności światopoglądowej państwa, ale walkę z religią, inspirowaną założeniami ideologicznymi. Choć podjęta przez władze partyjno-rządowe walka zakończyła się w sferze publiczno-prawnej sukcesem, w takim znaczeniu, że religia i sprawy wyznaniowe usunięto poza mury szkolne, społeczeństwo w znacznej liczbie, w tym młodzież, manifestowali, w możliwy sposób, więź z Kościołem i przywiązanie do wartości religijnych.

\footnotetext{
132 AAG, S. Wyszyński, Pro memoria, 24 V 1961 r.

133 AAG, S. Wyszyński, Pro memoria, 27 V 1961 r.

134 AAG, S. Wyszyński, Pro memoria, 29 V 1961 r.
} 


\section{Bibliografia}

Connelly J., Zniewolony uniwersytet. Sowietyzacja szkolnictwa wyższego w Niemczech wschodnich, Czechach i Polsce 1945-1956, Warszawa 2013.

Draus J., Terlecki R., Historia wychowania, t. 2: Wiek XIX $i$ XX, Wydawnictwo WAM: WSFP „Ignatianum”, Kraków 2005.

Dudek A., Gryz R., Komuniści i Kościół w Polsce (1945-1989), Kraków 2006.

Gałaszewska-Chilczuk D., „,Wrogie” uniwersytety. Polityka państwa komunistycznego wobec Katolickiego Uniwersytetu Lubelskiego i Uniwersytetu Marii Curie-Skłodowskiej (1944-1969), Warszawa 2013.

Gomułka W., Przemówienia 1961, Książka i Wiedza, Warszawa 1962.

Kosiński K., O nowa mentalność. Życie codzienne w szkołach 1945-1956, Warszawa 2000.

Kosiński K., Polski przypadek szczególny, „Pamięć i Sprawiedliwość” 2014, nr 2.

Krawczyk M., Urząd do spraw Wyznań a funkcjonowanie seminariów duchownych i stużba wojskowa kleryków - studium historyczno-prawne, „Zeszyty Naukowe Uniwersytetu Przyrodniczo-Humanistycznego w Siedlcach. Seria: Administracja i Zarządzanie”, 2016, nr 108.

Mauersberg S., Nauczyciel wobec indoktrynacji komunistycznej w latach 1947-1956, „Przegląd Historyczno-Oświatowy" 2004, nr 3/4.

Mauersberg S., Walczak M., Szkolnictwo polskie po drugiej wojnie światowej (1944-1956), Warszawa - Radom 2005.

Mezglewski A., Misztal H., Stanisz P., Prawo wyznaniowe, Warszawa, 2011.

Pamiętniki, dzienniki i relacje jako źródta do badań historycznych (XVIII-XX wiek), K. Karolczak (red.), Kraków 2011.

Wojdon J., Świat elementarzy. Obraz rzeczywistości w podręcznikach do nauki czytania w krajach bloku radzieckiego, Warszawa 2015.

Wołoszyn J.W., Szkoła jako instrument politycznej legitymizacji władzy partii komunistycznej w Polsce (1944-1989), Lublin 2015.

Wyszyński S., Dzieła zebrane, t. 7: 1961, Warszawa 2008.

Wyszyński S., Pro memoria, I. Czarcińska, A. Gałka (red. i oprac.), Warszawa 2018.

Wyszyński S., Pro memoria, t. 1: 1948-1952, P. Skibiński (red. i oprac.), Warszawa - Gniezno 2017.

Wyszyński S., Pro memoria, t. 2: 1953, E. Czaczkowska (red. i oprac.), Warszawa - Gniezno 2017.

Wyszyński S., Pro memoria, t. 5: 1958, M. Krupecka (red. i oprac.), Warszawa - Gniezno 2018.

Żaryn J., Dzieje Kościoła katolickiego w Polsce (1944-1989), Warszawa 2003. 